Kampus 4 Universitas Ahmad Dahlan

Jl. Ringroad Selatan, Tamanan, Banguntapan, Bantul

Daerah Istimewa Yogyakarta 55191

Telp. : (0274) 563515 Fax. : (0274) 564604

e-mail : ihtifaz@uad.ac.id

Vol.1, No 1\&2, Juni-Desember 2018, pp. 51-67

ISSN p:2622-4755 e:2622-4798.

DOI: https://doi.org/10.12928/ijiefb.v1i1.274

\title{
Analisis Prediksi Kebangkrutan dan Rasio Keuangan Bank Umum Syariah dengan Metode Altman Z-Score pada Tahun 2011-2015
}

\section{Rais Sani Muharrami ${ }^{1 *}$, Sinta $^{1}$}

${ }^{1}$ Surakarta State Islamic Institute, Jalan Pandawa, Dusun IV, Pucangan, Kartasura, Kabupaten Sukoharjo, Jawa Tengah 57168

*e-mail: raiztsan@gmail.com 


\section{Analisis Prediksi Kebangkrutan dan Rasio Keuangan Bank Umum Syariah dengan Metode Altman Z-Score pada Tahun 2011-2015}

\author{
Rais Sani Muharrami ${ }^{1 *}$, Sinta ${ }^{1}$ \\ ${ }^{1}$ Surakarta State Islamic Institute, Jalan Pandawa, Dusun IV, Pucangan, \\ Kartasura, Kabupaten Sukoharjo, Jawa Tengah 57168 \\ *e-mail: raiztsan@gmail.com
}

\begin{abstract}
The purpose of this research is to perform a comparative analysis of bankruptcy prediction and financial ratio related to Bank Umum Syariah Devisa and Bank Umum Syariah non Devisa. This research applied Altman model on Bank Umum Syariah Devisa and Bank Umum Syariah non Devisa to explain its bankruptcy prediction, while Mann Withney test is used to show a comparative analysis on its financial ratio related to bankruptcy. Data was use in this research is time series data, the data from 2011 up to 2015. The data is obtained from publication in Otoritas Jasa Keuangan (OJK) and publication in each bank's website. The sampling techniques using purposive sampling methods. This research can be concluding that there is no difference between Bank Umum Syariah Devisa and Bank Umum Syariah non Devisa on Bankruptcy prediction with Altman model. In financial ratios related to bankruptcy exposure such as liquidity, Profitability, and Productivity has not significant difference. While insolvency ratio at Bank Umum Syariah Devisa and Bank Umum Syariah non Devisa found have differences. Bankruptcy prediction at Bank Umum Syariah Devisa and Bank Umum Syariah non Devisa is found not difference.
\end{abstract}

\section{Keywords:}

Islamic Banking Devisa and non Devisa, Bankrupcty Prediction, Altman Z-Score, Financial Ratio

\begin{abstract}
Abstrak
Tujuan penelitian ini adalah untuk melakukan analisis komparatif prediksi kebangkrutan dan rasio keuangan terkait dengan Bank Umum Syariah Devisa dan Bank Umum Syariah non Devisa. Penelitian ini menggunakan model Altman pada Bank Umum Syariah Devisa dan Bank Umum Syariah non Devisa untuk menjelaskan prediksi kebangkrutannya, sedangkan uji Mann Withney digunakan untuk menunjukkan analisis komparatif terhadap rasio keuangan terkait dengan kebangkrutan. Data yang digunakan dalam penelitian ini
\end{abstract}

Ihtifaz: Journal of Islamic Economics, Finance, and Banking

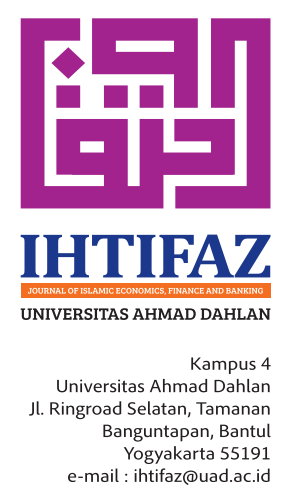


adalah data time series, data dari tahun 2011 hingga 2015. Data diperoleh dari publikasi di Otoritas Jasa Keuangan (OJK) dan publikasi di masing-masing IHTIFAZ - JIEFB situs web bank. Teknik pengambilan sampel menggunakan metode purposive sampling. Penelitian ini dapat disimpulkan bahwa tidak ada perbedaan antara Bank Umum Syariah Devisa dan Bank Umum Syariah non Devisa terhadap prediksi Kepailitan dengan model Altman. Dalam rasio keuangan terkait dengan eksposur pailit seperti likuiditas, profitabilitas, dan produktivitas tidak memiliki perbedaan yang signifikan. Sedangkan rasio insolvensi di Bank Umum Syariah Devisa dan Bank Umum Syariah non Devisa ditemukan memiliki perbedaan. Untuk prediksi kebangkrutan di Bank Umum Syariah Devisa dan Bank Umum Syariah non Devisa ditemukan tidak ada perbedaan.

\section{Kata Kunci:}

Perbankan Syariah Devisa dan non Devisa, Prediksi Kebangkrutan, Altman Z-Score, Rasio Keuangan

\section{PENDAHULUAN}

Risiko terburuk bagi setiap perusahaan adalah kebangkrutan. Bagi industri perbankan, kebangkrutan bisa terjadi di sebabkan oleh berbagai faktor, salah satunya adalah disebabkan adanya krisis. (Muhammad, 2005). Potensi kebangkrutan bisa terjadi kapan saja, sehingga diperlukan mitigasi dan pencegahan yang preventif dan berkelanjutan demi menjaga keberlangsungan perusahaan, dalam hal ini industri perbankan.

Sebagai sebuah entitas perbankan yang baru tumbuh, maka isu kebangkrutan menjadi hal yang patut untuk diwaspadai. Isu terbaru mengenai ancaman kebangkrutan terbaru menerpa Bank Muamalat Indonesia. Isu ini dipicu dengan rasio NPF Bank Muamalat yang terlampau tinggi. Tercatat dalam laporan keuangan Bank Muamalat yang dirilis Otoritas Jasa Keuangan lebih dari 7\%, ini melampaui batas maksimal 5\%. Sementara kondisi Bank Muamalat berdasarkan laporan keuangan September 2017 total aset Bank Muamalat per September 2017 sebesar Rp 57,71 triliun tumbuh 3,46\% dibanding September 2016 Rp 55,78 triliun. Laba bersih tahun berjalan tercatat Rp 34,17 miliar lebih rendah dibandingkan periode September 2016 Rp 37,95 miliar (OJK, 2017).

Kegagalan suatu perbankan dapat menyebabkan efek domino bagi perusahaan-perusahaan ataupun perbankan lain. Dampak sistemik menjadi perhatian karena sesungguhnya apabila terlihat ada potensi kebangkrutan dari suatu bank. Keresahan nasabah akan mudah menyebar dan akan berakibat juga pada bank-bank yang sehat. Apabila suatu bank dinyatakan sebagai bank gagal, ada 2 pilihan yang dapat dilakukan, yaitu diselamatkan atau tidak diselamatkan. Penangannya diserahkan kepada Lembaga Penjamin Simpanan (Kusdiana, 2014).

Kebangkrutan sebuah bank dapat dipicu oleh berbagai faktor. Bank dapat bangkrut dan harus ditutup kalau kinerjanya buruk akibat 
naiknya kredit macet, atau aset bermasalah secara signifikan. Penyebab lain adalah banyaknya pemilik bank yang ikut campur tangan dalam operasional bank sehari-hari. Pemberian kredit yang tidak hati-hati, sehingga kurang memperhatikan sama sekali aspek manajemen risiko, good governance, dan kehati-hatian. Jadi, jelas bahwa pemicu bangkrutnya sebuah bank bisa datang dari internal bank itu sendiri maupun faktor eksternal sebagai dampak dari kondisi ekonomi yang memburuk.

Dengan melihat fenomena-fenomena kebangkrutan perbankan yang sebelumnya telah terjadi, peneliti tertarik untuk meneliti prediksi kebangkrutan perbankan. Peneliti menganggap bahwa kebangkrutan suatu perbankan merupakan hal yang harus dihindari karena dampak kebangkrutan suatu bank dapat dilihat dan diukur melalui laporan keuangannya. Pengukuran tersebut dilakukan dengan cara menganalisis laporan keuangan yang dikeluarkan oleh bank yang bersangkutan. Perusahaan dapat mengetahui keadaan serta perkembangan finansial perusahaan serta hasil-hasil yang telah dicapai di waktu lampau dan diwaktu yang sedang berjalan. Selain itu dengan melakukan analisis keuangan di waktu lampau, maka dapat diketahui kelemahankelemahannya serta hasil-hasilnya yang dianggap telah cukup baik, dan mengetahui potensi kebangkrutan perbankan tersebut.

Kesalahan prediksi terhadap kelangsungan operasi suatu perusahaan di masa yang akan datang dapat berakibat fatal yaitu kehilangan pendapatan atau investasi yang telah ditanamkan pada suatu perusahaan. Dengan kemampuan manajerial yang dimiliki, para manajer perusahaan diharapkan mampu mengubah ancaman lingkungan yang tidak menentu ini menjadi berbagai peluang usaha yang menguntungkan.

Salah satu indikator utama yang dijadikan dasar penilaian adalah laporan keuangan bank yang bersangkutan. Berdasarkan laporan keuangan akan dapat dihitung sejumlah rasio keuangan yang lazim dijadikan dasar prediksi kebangkrutan. Hasil analisis laporan keuangan akan membantu mengintepretasikan berbagai hubungan serta kecenderungan yang dapat memberikan dasar pertimbanganmengenai prediksi masa depan bank apakah dapat bertahan atau tidak (Munawir, 2002).

Banyaknya model prediksi kesulitan keuangan dan kebangkrutan perusahaan yang telah dikembangkan, model Z-Score muncul sebagai primadona yang banyak digunakan para pakar ekonomi dunia. Model Z-Score pertama kali diperkenalkan oleh Edward I. Altman dalam bukunya yang berjudul Corporate Financial Distress: A Complete Guide to Predicting, Avoiding, and Dealing with Bancruptcy. Model Z-Score adalah suatu alat yang digunakan untuk meramalkan tingkat kebangkrutan perusahaan dengan menghitung nilai dari beberapa rasio lalu kemudian dimasukkan dalam suatu persamaan diskriminan (Nurdin, 2012). 
Munculnya berbagai model prediksi kebangkrutan merupakan antisipasi dan sistem peringatan dini (early warning system) terhadap kemungkinan akan terjadinya krisis keuangan. Tujuan dari sistem peringatan dini sebagai sarana untuk mengidentifikasikan bahkan memperbaiki kondisi sebelum sampai pada kondisi krisis atau kebangkrutan.

Altman menggunakan multivariate discriminant analysis (MDA) dalam menguji manfaat lima rasio keuangan dalam memprediksi kebangkrutan. Menurut Altman (2000), teknik penggunaan MDA mempunyai kelebihan dalam mempertimbangkan karakteristik umum dari perusahaanperusahaan yang relevan, termasuk interaksi antar perusahaan tersebut. Di samping itu, pendekatan MDA dapat mengkombinasikan berbagai rasio menjadi suatu model prediksi yang berarti dan dapat digunakan untuk seluruh perusahaan, baik perusahaan publik, pribadi, manufaktur, ataupun perusahaan jasa dalam berbagai ukuran.

Penelitian yang dilakukan Hadi (2012) membandingkan antara model Altman Z-Score, model Zmijewski, dan model Springate, mana yang merupakan predictor delisting terbaik dari sampel berupa perusahaan manufaktur yang delisting dari Bursa Efek Indonesia periode 2003-2007. Hasil penelitian menyimpulkan bahwa model Altman Z-Score merupakan prediktor delisting terbaik. Hasil penelitian tersebut dapat dijadikan acuan dalam pemilihan model Z-Score sebagai prediktor kebangkrutan.

Pada penelitian yang dilakukan oleh Kusdiana (2014) menganalisis model CAMEL dan Altman's Z-Score dalam memprediksi kebangkrutan bank umum di Indonesia. Berdasarkan hasil uji ketepatan model prediksi kebangkrutan Altman's Z-Score memiliki tingkat ketepatan prediksi lebih tinggi dalam memprediksi kebangkrutan bank umum di Indonesia dibandingkan dengan model CAMEL.

Tingkat ketepatan model predisksi kebangkrutan Altman's Z-Score selama lima tahun (2007-2011) sebesar 100\% dengan tingkat kesalahan tipe I (false negative) dan tipe kesalahan II (false positive) sebesar $0 \%$. Sedangkan hasil uji ketepatan model CAMEL ditahun 2008, tingkat ketepatan model prediksi sebesar 95,2\% dengan kesalahan tipe II (false positive) adalah $0 / 3$ atau $0 \%$ dan kesalahan tipe I (false negative) adalah $1 / 18$ atau 5,55\%. Dengan demikian hasil uji model fit maupun uji ketepatan model prediksi kebangkrutan model Altman's Z-Score dapat dinyatakan sebagai model yang dapat memprediksi kebangkrutan bank umum di Indonesia dengan tingkat ketepatan prediksi lebih tinggi dari model CAMEL.

Berdasarkan teori yang telah dikemukakan di atas, maka dalam penelitian ini akan digunakan model Altman's Z-Score sebagai alat untuk memprediksi kebangkrutan pada perusahaan perbankan di Indonesia. Dalam penelitian Altman (1986), Model Altman (Z-Score) merupakan salah satu model analisis multivariate yang berfungsi untuk memprediksi kebangkrutan perusahaan dengan tingkat ketepatan dan keakuratan 
yang relatif dapat dipercaya. Model ini memiliki akurasi mencapai 95\% jika menggunakan data 1 tahun sebelum kondisi kebangkrutan.

\section{KERANGKA TEORI DAN HIPOTESIS}

\section{Kebangkrutan}

Penelitian yang dilakukan Luciana (2004) mengartikan kondisi financial distress sebagai suatu kondisi dimana perusahaan mengalami delisted akibat laba bersih dan nilai ukur ekuitas negatif berturutturut serta perusahaan tersebut telah dimerger. Sementara Kahya dan Theodossiou (1999), mengkategorikan kondisi financial distress berdasarkan kriteria debt default, yaitu terjadinya kegagalan membayar utang atau terdapat indikasi kegagalan membayar utang (debt default) dengan melakukan negosiasi ulang dengan kreditur atau institusi keuangan lainnya, dimana informasi mengenai debt default dan indikasi debt default diambil dari informasi Wall Street Journal Index (WSJI). Kebangkrutan biasanya diartikan sebagai kegagalan perusahaan dalam menjalankan operasi perusahaan untuk menghasilkan laba. Kebangkrutan juga dapat disebut likuidasi perusahaan atau penutupan perusahaan insolvabilitas.

Kebangkrutan merupakan suatu keadaan dimana perusahaan gagal atau tidak mampu lagi memenuhi kewajiban-kewajibannya baik jangka panjang maupun jangka pendek. Hal tersebut karena ketidakcukupan dana yang dimiliki oleh perusahaan untuk menjalankan usahanya. Sehingga untuk mengembalikan pinjaman, membiayai operasi perusahaan dan kewajiban-kewajiban yang harus dipenuhi bisa ditutup dengan laba atau aktiva yang dimiliki.

\section{Faktor-Faktor Penyebab Kebangkrutan}

Beberapa faktor yang dapat menjadi penyebab kebangkrutan suatu perusahaan adalah sebagai berikut (Janch \& Glueck, 1995 dalam Adnan \& Kurniasih, 2000):

1. Faktor umum
a. Sektor ekonomi
b. Faktor sosial
c. Sektor teknologi
d. Sektor pemerintah

2. Faktor Eksternal Perusahaan
a. Sektor pelanggan
b. Sektor pemasok
c. Sektor pesaing

3. Faktor Internal Perusahaan

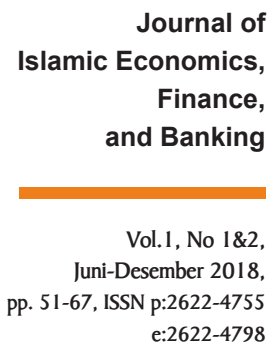




\section{Studi Empiris Prediksi Kebangkrutan}

Model Altman mempunyai manfaat bagi perusahaan untuk IHTIFAZ - JIEFB memperoleh peringatan awal kebangkrutan dan kelanjutan usahanya (Aminah et.al, 2015). Semakin awal suatu perusahaan memperoleh peringatan kebangkrutan, semakin baik bagi pihak manajemen karena pihak manajemen bisa melakukan perbaikan-perbaikan dan dapat memberikan gambaran dan harapan yang mantap terhadap nilai masa depan perusahaan tersebut.

Studi Beaver (1966) menggunakan univariate discriminant analysis dalam memprediksi kebangkrutan dan menyimpulkan bahwa rasio working capital funds flow/total aset dan net income/total asets mampu membedakan perusahaan yang akan pailit dengan yang tidak pailit secara tepat masing-masing sebesar 90 persen dan 88 persen dari sampel yang digunakan (Argyris dalam Endri, 2009).

Altman (1968) mempelopori penggunaan multivariate discriminant analysis (MDA) dalam memprediksi corporate failure. MDA menyatukan informasi yang diperoleh dari multivariate independent variabels (seperti ratio-rasio) menjadi satu nilai tunggal (single score) yang digunakan untuk mengklasifikasi suatu observasi ke dalam mutually exclusive groups. Dalam hal ini, MDA lebih menonjol dibandingkan univariate analysis, karena MDA mempertimbangkan seluruh profil variabel dari suatu perusahaan termasuk interaksi antar variabel tersebut (Endri: 2009).

Deakin (1972) mengkritik sifat univariat dari Model Beaver sebelumnya dan diubah modelnya dalam perspektif multivariat untuk mencapai akurasi tertinggi. Mossman (1998) membandingkan beberapa model kebangkrutan dan dinilai Altman Model sebagai prediktor terbaik untuk kebangkrutan karena rasio terbangun secara alami, sedangkan rasio adalah prediktor yang terbaik dalam menemukan kebangkrutan (Deakin dan Mossman dalam Jan, 2015). Selain itu, karena akurasi dan popularitas model kebangkrutan Altman (Altman, 2000) ditujukan kepada semua kritik yang dibuat pada model kebangkrutan awal.

Penggunaan model Altman sebagai salah satu pengukuran kinerja kebangkruatn tidak bersifat tetap atau stagnan melainkan berkembang dari waktu kewaktu, dimana pengujian dan penemuan model terus diperluas oleh altman hingga penerapannya tidak hanya pada perusahaan manufaktur publik saja tapi sudah mencakup perusahaan manufaktur non publik, perusahaan non manufaktur, dan perusahaan obligasi korporasi.

\section{Model prediksi kebangkrutan Altman's Z-Score}

Rumus yang digunakan dalam model Altman (2000) sebagai berikut: Jika perusahaan publik $Z=1.2 \times 1+1.4 \times 2+3.3 \times 3+0.6 \times 4+.999 \times 5$ 
Jika perusahaan swasta $Z=0.717 \times 1+0.847 \times 2+3.107 \times 3+0.420 \times 4$ $+0.998 \times 5$

Jika perusahaan jasa $Z=6.56 \times 1+3.26 \times 2+6.72 \times 3+1.05 \times 4$

Sebanyak tiga formula yang digunakan dalam model kebangkrutan Altman seperti yang ditunjukkan diatas. Untuk perusahaan manufaktur formula dibagi menjadi dua yaitu publik dan swasta. Sementara memprediksi kebangkrutan industri jasa seperti industri perbankan Altman memperkenalkan model perusahaan jasa secara terpisah (Altman, 2000).

\section{Altman Model untuk Perusahaan Jasa}

$$
Z=6.56 \times 1+3.26 \times 2+6.72 \times 3+1.05 X 4
$$

\section{Keterangan:}

X1 = Modal Kerja/Total Aset

X2 = Laba Ditahan/Total Aset

X3 = Laba sebelum Bunga dan Pajak/Total Aset

X4 = Nilai Buku Ekuitas/Nilai Buku Total Kewajiban

Menurut (Altman, 2000) jika nilai skor z ditemukan lebih besar dari 2,90 perusahaan akan dinilai dalam zona aman, jika nilai Z-Score ditemukan kurang dari 1,21 perusahaan akan dinilai dalam zona bangkrut. Namun, jika nilai Z-Score berada di antara 1,21 $<Z<2,9$ perusahaan dikatakan dalam zona abu-abu. Dan teknis zona abu-abu juga disebut aman.

Keempat rasio inilah yang akan digunakan untuk menganalisis laporan keuangan sebuah perusahaan jasa untuk kemudian mendeteksi kemungkinan terjadinya kebangkrutan pada perusahaan tersebut. Uraian masing-masing rasio tersebut adalah sebagai berikut (Altman, 2000):

a. Modal kerja terhadap total aset digunakan untuk mengukur likuiditas aktiva perusahaan relatif terhadap total kapitalisasinya atau untuk mengukur kemampuan perusahaan dalam memenuhi kewajiban jangka pendek

b. Laba ditahan terhadap total aset digunakan untuk mengukur profitabilitas kumulatif. Rasio ini mengukur akumulasi laba perusahaan selama perusahaan beroperasi

c. Pendapatan sebelum pajak dan bunga terhadap total aset digunakan untuk mengukur produktivitas yang sebenarnya dari aktiva perusahaan

d. Nilai buku ekuitas terhadap nilai buku dari utang digunakan untuk mengukur seberapa banyak aktiva perusahaan dapat turun nilainya sebelum jumlah utang lebih besar daripada aktivanya dan perusahaan menjadi pailit. 


\section{HIPOTESIS}

Tujuan pertama dari penelitian ini adalah untuk melakukan analisis IHTIFAZ - JIEFB perbandingan pada kebangkrutan BUSN Devisa dan BUSN non Devisa. Sebagai BUSN Devisa dan BUSN non Devisa tentunya memiliki perbedaan risiko, analisis perbandingan kebangkrutan akan membawa kita untuk memahami fakta bahwa, apakah ada pengaruh yang signifikan dari perbedaan risiko dan kinerja keuangan pada kesehatan keuangan dari BUSN Syariah Devisa dan non Devisa. Dan karenanya, hipotesis berikut ini dikembangkan.

H1: Bank Umum Syariah Devisa dan Bank Umum Syariah non Devisa berbeda pada profil kebangkrtuan

Tujuan kedua dari penelitian ini adalah untuk melakukan analisis perbandingan pada indikator kinerja keuangan perbankan syariah yang berkaitan dengan kebangkrutan. Altman mengedepankan argumen bahwa likuiditas, profitabilitas, produktivitas, dan insolvensi adalah indikator kinerja teratas yang menyebabkan kebangkrutan.

H2: Bank Umum Syariah Devisa dan non Devisa berbeda pada indikator kinerja yang berkaitan dengan kebangkrutan.

H2a: Bank Umum Syariah Devisa dan non Devisa berbeda pada indikator likuiditas yang berkaitan dengan kebangkrutan.

H2b: Bank Umum Syariah Devisa dan non Devisa berbeda pada indikator profitabilitas yang berkaitan dengan kebangkrutan.

H2c: Bank Umum Syariah Devisa dan non Devisa berbeda pada indikator produktifitas yang berkaitan dengan kebangkrutan.

H2d: Bank Umum Syariah Devisa dan non Devisa berbeda pada indikator insolvensi yang berkaitan dengan kebangkrutan.

\section{METODE PENELITIAN}

\section{Waktu dan Wilayah Penelitian}

Penelitian ini dilakukan mulai dari bulan Maret 2016 sampai Februari 2017. Wilayah penelitian ini dilakukan di Bank Umum Syariah Devisa dan non Devisa, tetapi peneliti tidak secara langsung kekantor objek penelitian melainkan peneliti mengambil data di situs resmi BI (www. bi.go.id) atau OJK (www.ojk.go.id) dan situs resmi masing-masing Bank Umum Syariah Devisa dan non Devisa periode 2011-2015.

\section{Jenis Penelitian}

Jenis penelitian yang digunakan adalah penelitian kuantitatif dengan pendekatan studi yang bersifat deskriptif dan komparatif. Penelitian kuantitatif merupakan suatu proses penelitian untuk menemukan pengetahuan yang menggunakan data berupa angka sebagai alat menganalisis mengenai tujuan yang ingin kita ketahui (Kasiram, 2008). 
Jenis data yang digunakan dalam penelitian ini adalah data sekunder dalam bentuk time series yang bersifat kuantitatif yaitu data dalam bentuk angka-angka.

Penelitian ini mengungkap tentang keadaan keuangan Bank Umum Syariah Devisa dan non Devisa dengan menggunakan metode Discriminant Analysis Altman Z-Score dan melihat perbedaan pada indikator kebangkrutan dengan menggunakan atau melukiskan keadaan obyek penelitian, berdasarkan fakta-fakta yang tampak atau bagaimana adanya melalui pengolahan data-data.

\section{Populasi, Sampel, dan Teknik Pengambilan Sampel}

Populasi yang digunakan dalam penelitian ini adalah seluruh Bank Umum Devisa dan non Devisa yang ada dibawah pengawasan Bank Indonesia dan Otoritas Jasa Keuangan sejumlah 13 Bank Umum Syariah. Sampel yang diambil dalam penelitian ini sejumlah 10 bank dengan menggunakan 50 data yang merupakan data Laporan Keuangan Bank Umum Syariah Devisa dan non Devisa di Indonesia yang diperoleh dari website masing-masing bank.

Teknik pengambilan sampel dalam penelitian ini yaitu menggunakan teknik Non Probability sampling. Jenis Non Probability sampling yang digunakan ialah Purposive sampling. Metode Purposive sampling adalah metode pengambilan sampel berdasarkan pertimbangan tertentu dan harus mewakili populasi yang diteliti. Adapun pertimbangan yang dilakukan dalam pengambilan sampel yaitu:

1. Bank Syariah yang masuk dalam kategori Bank Devisa dan non Devisa dari tahun 2011-2015.

2. Bank Syariah yang menerbitkan laporan keuangan tahunan dari tahun 2011-2015.

\section{Data dan Sumber Data}

Data sekunder yang digunakan dalam penelitian ini adalah laporan keuangan bank yang khususnya berada dalam neraca, laporan laba rugi. Sumber data dari penelitian ini diperoleh dari www.bi.go.id, www. ojk.go.id dan situs resmi masing-masing Bank Umum Syariah Devisa dan non Devisa, sedangkan data yang diperlukan dalam penelitian ini berupa gambaran umum perusahaan atau profil perusahaan dan laporan keuangan Bank Umum Syariah Devisa dan non Devisa periode 2011-2015.

\section{Variabel Penelitian}

Dalam penelitian ini variabel yang digunakan adalah perbandingan prediksi kebangkrutan dan rasio keuangan Bank Syariah Devisa dan non Devisa dengan menggunakan metode Altman Z-Score. Sedangkan variabel-variabel dalam metode Altman Z-Score adalah: 
1. Z-Score

2. $\mathrm{X}_{1}$ (Working capital to total assets/WCTA)

IHTIFAZ - JIEFB

3. $\mathrm{X}_{2}$ (Retained earnings to total assets/RETTA)

4. $\mathrm{X}_{3}$ (Earnings before interest and taxes to total assets/EBTTA)

5. $\mathrm{X}_{4}$ (Market value equity to book value of total debt/MVEtoMVD)

\section{Definisi Operasional Variabel}

1. Z-Score

Z-Score adalah variabel yang digunakan untuk menunjukkan kebangkrutan.

2. $\mathrm{X}_{1}$ (Working capital to total assets)

Merupakan rasio yang menunjukkan kemampuan perusahaan untuk menghasilkan modal kerja bersih dari keseluruhan total aktiva yang dimilikinya. Rumusnya adalah sebagai berikut:

$\mathrm{X}_{1}=\frac{\text { Modal Kerja }}{\text { Total Aset }}$

Modal Kerja adalah aktiva lancar dikurangi hutang lancar. Modal kerja negatif kemungkinan besar akan menghadapi masalah dalam menutupi kewajiban jangka pendeknya karena tidak tersedianya aktiva lancar yang cukup untuk memenuhi kewajiban tersebut (Kasmir, 2014).

3. $\mathrm{X}_{2}$ (Retained earnings to total assets)

Merupakan rasio ini menunjukkan kemampuan perusahaan untuk menghasilkan laba ditahan dari total aktiva perusahaan. Rasio ini juga memberikan informasi mengenai umur perusahaan, karena semakin lama perusahaan beroperasi memungkinkan untuk memperlancar akumulasi laba ditahan. Rasio ini Rumus yaitu:

$\mathrm{X}_{2}=\frac{\text { Laba Ditahan }}{\text { Total Aset }}$

4. $\mathrm{X}_{3}$ (Earnings before interest and taxes to total assets)

Rasio ini menunjukkan kemampuan perusahaan untuk menghasilkan laba dari aktiva perusahaan, sebelum pembayaran bunga dan pajak (Kasmir, 2014: 198). Namun dalam penelitian ini, hal yang menjadi objek penelitian adalah kondisi keuangan Bank Umum Syariah Devisa dan non Devisa yang telah menjalankan kegiatan usahanya serta operasionalnya dengan prinsip syariah.

Sehingga tidak ada akun yang bernama EBIT dalam laporan keuangannya, oleh karena itu akun ini dalam laporan keuangan Bank Umum Syariah Devisa maupun non Devisa dikenal dengan nama "Laba sebelum pajak penghasilan". Rumus dari rasio ini adalah:

$\mathrm{X}_{3}=\frac{\text { Laba Sebelum pajak penghasilan }}{\text { Total Aset }}$ 
5. $\mathrm{X}_{4}$ (Book value of equity to book value of total debt)

Journal of

Merupakan rasio yang digunakan untuk mengukur sejauh mana aktiva perusahaan dibiayai dari hutang. Rumusnya yaitu:

$\mathrm{X}_{4}=\frac{\text { Nilai buku ekuitas }}{\text { Total Kewajiban }}$

Islamic Economics,

Finance,

and Banking

Variabel-variabel di atas kemudian dimasukkan ke dalam formula diskriminan alternatif yang dikembangkan oleh Altman dan telah

dimodifikasi, maka fungsi model Altman Z-Score tersebut adalah:

Z-Score $=6.56 X_{1}+3.26 X_{2}+6.72 X_{3}+1.05 X_{4}$

Hasil dari perhitungan model Altman bila diinterpretasikan adalah sebagai berikut:

1) Z-Score $>2,90$

Perusahaan tidak mempunyai masalah dengan kondisi keuangan atau dengan kata lain aman dari kebangkrutan.

2) $1,21>$ Z-Score $<2,90$

Perusahaan akan mengalami kebangkrutan, jika tidak melakukan perbaikan yang berarti dalam manajemennya maupun dalam struktur keuangannya.

3) Z-Score $<1,21$

Perusahaan mengalami ancaman kebangkrutan yang serius.

\section{Teknik Analisis Data}

Analisis data dalam penelitian ini dilakukan secara kuantitatif menggunakan analisis deskriptif. Ada dua tahapan dari analisis ini, tahapan pertama pengolahan data yang diperoleh dari aporan keuangan dengan menggnakan model Altman Z-Score. Tahapan yang kedua adalah pengolahan data dengan menggunakan teknik statistik yaitu uji Mann-Whitney Test. Pengujian ini sering disebut sebagai pengujian uji $\mathrm{U}$, karena untuk menguji hipotesis nol, kasus dihitung angka statistik yang disebut U (Supranto, 2009). Uji Mann-Whitney merupakan salah satu uji non parametric yang sangat kuat dan sebagai alternatif uji parametric t test (Suliyanto, 2014).

\section{HASIL}

Tabel 1 menunjukkan hasil Z-Score (2011-2015) dari 10 Bank Umum Syariah yang dijadikan sampel. Nilai Z-Score setiap tahunnya yang dihitung untuk masing-masing bank dari tahun 2011-2015, dan peringkat Z-Score dihitung berdasarkan nilai rata-rata Z-Score selama 5 tahun. Tabel 1 di bawah ini menjelaskan hasul dan peringkat Z-Score dari perbankan syariah devisa dan non devisa (2011-2015) sebagai berikut. 
Tabel 1. Hasil dan peringkat Z-Score dari Perbankan Syariah Devisa dan Non Devisa (2011-2015)

\begin{tabular}{|c|c|c|c|c|c|c|c|c|}
\hline IHTIFAZ - JIEFB & Nama Bank & 2011 & 2012 & 2013 & 2014 & 2015 & $\begin{array}{c}\text { Rata- } \\
\text { rata }\end{array}$ & $\begin{array}{l}\text { Ranking } \\
\text { Z-Score }\end{array}$ \\
\hline & \multicolumn{8}{|l|}{ Bank Devisa } \\
\hline & PT. BNI Syariah & 6,373 & 5,937 & 5,254 & 6,267 & 6,257 & 6,018 & 5 \\
\hline & $\begin{array}{l}\text { PT. Bank Syariah } \\
\text { Mega Indonesia }\end{array}$ & 4,686 & 5,258 & 5,582 & 5,760 & 5,936 & 5,444 & 9 \\
\hline & $\begin{array}{l}\text { PT. Bank Muamalat } \\
\text { Indonesia }\end{array}$ & 5,968 & 5,589 & 5,730 & 5,611 & 5,237 & 5,627 & 8 \\
\hline & $\begin{array}{l}\text { PT. Bank Syariah } \\
\text { Mandiri }\end{array}$ & 5,979 & 5,859 & 5,731 & 6,143 & 5,892 & 5,921 & 6 \\
\hline & \multicolumn{8}{|l|}{ Bank Non Devisa } \\
\hline & PT. BCA Syariah & 7,276 & 6,895 & 6,748 & 7,878 & 8,693 & 7,498 & 2 \\
\hline & $\begin{array}{l}\text { PT. Bank BRI } \\
\text { Syariah }\end{array}$ & 5,622 & 5,505 & 5,371 & 5,179 & 5,360 & 5,408 & 10 \\
\hline & $\begin{array}{l}\text { PT. BPD Jawa Barat } \\
\text { Banten Syariah }\end{array}$ & 7,449 & 6,589 & 6,259 & 6,937 & 7,128 & 6,872 & 4 \\
\hline & $\begin{array}{l}\text { PT. Bank Panin } \\
\text { Syariah }\end{array}$ & 8,365 & 8,381 & 7,302 & 6,949 & 7,859 & 7,182 & 1 \\
\hline & $\begin{array}{l}\text { PT. Bank Victoria } \\
\text { Syariah }\end{array}$ & 8,063 & 5,978 & 7,059 & 7,356 & 6,759 & 7,043 & 3 \\
\hline & $\begin{array}{l}\text { PT. Bank Syariah } \\
\text { Bukopin }\end{array}$ & 6,073 & 5,253 & 5,047 & 6,132 & 6,414 & 5,784 & 7 \\
\hline & Rata-Rata & 6,59 & 6,12 & 6,01 & 6,42 & 6,49 & 6,34 & - \\
\hline
\end{tabular}

Sumber: Data Diolah (2018)

Sejalan dengan tujuan pertama yaitu untuk melakukan analisis perbandingan pada profil kebangkrutan antara Bank Umum Syariah Devisa dan Bank Umum Syariah non Devisa, tabel 1 di atas menunjukkan bahwa, rata- rata nilai Z-Score Bank Umum Syariah non Devisa lebih baik daripada Bank Umum Syariah Devisa. Hal ini dapat dilihat pada peringkat 1, 2, 3, dan 4 yang dimiliki Bank Syariah non Devisa. Namun peringkat terkecil juga berada pada Bank Umum Syariah non Devisa yaitu Bank BRI Syariah. Sedangkan Bank Umum Syariah Devisa memiliki peringkat menengah.

Atas dasar Z-Score kinerja Bank Panin Syariah memiliki peringkat terbaik, diikuti oleh BCA Syariah, Bank Victoria Syariah, Bank Jabar Banten Syariah, BNI Syariah, Bank Syariah Mandiri, Bank Syariah Bukopin, Bank Muamalat, Bank Mega Syariah, dan yang terakhir BRI Syariah. Dari semua nilai Z-Score berdasarkan ketentuan tidak ada bank yang terprediksi bankrut ataupun pada grey zone. Nilai rata-rata Z-Score tertinggi pada tahun 2015 dengan nilai 8,693 dan terendah pada tahun 2011 dengan nilai 4,686.

Tabel 2 di bawah ini menunjukkan peringkat masing-masing Bank Umum Syariah Devisa dan Bank Umum Syariah non Devisa atas 
dasar rasio keuangan yaitu Likuiditas, Profitabilitas, Produktifitas, dan Insolvensi. Altman menggunakan empat rasio ini sebagai prediktor atas kebangkrutan. Oleh karena itu, peringkat dibuat untuk setiap masing-masing bank atas dasar rasio yang digunakan oleh Altman untuk melihat analisis komparatif dari indikator kinerja yang berkaitan dengan kebangkrutan.

Tabel 2. Peringkat Berdasarkan Indikator Kinerja Keuangan

\begin{tabular}{|c|c|c|c|c|}
\hline Nama Bank & Likuiditas & Profitabilitas & Produktifitas & Insolvensi \\
\hline \multicolumn{5}{|l|}{ Bank Devisa } \\
\hline PT. BNI Syariah & 7 & 3 & 3 & 6 \\
\hline $\begin{array}{l}\text { PT. Bank Syariah Mega } \\
\text { Indonesia }\end{array}$ & 10 & 5 & 1 & 7 \\
\hline $\begin{array}{l}\text { PT. Bank Muamalat } \\
\text { Indonesia }\end{array}$ & 6 & 4 & 6 & 10 \\
\hline PT. Bank Syariah Mandiri & 5 & 1 & 4 & 9 \\
\hline \multicolumn{5}{|l|}{ Bank Non Devisa } \\
\hline PT. BCA Syariah & 4 & 6 & 5 & 2 \\
\hline PT. Bank BRI Syariah & 9 & 8 & 8 & 8 \\
\hline $\begin{array}{l}\text { PT. BPD Jawa Barat } \\
\text { Banten Syariah }\end{array}$ & 3 & 9 & 7 & 4 \\
\hline PT. Bank Panin Syariah & 1 & 7 & 2 & 1 \\
\hline PT. Bank Victoria Syariah & 2 & 2 & 10 & 3 \\
\hline PT. Bank Syariah Bukopin & 8 & 10 & 9 & 5 \\
\hline
\end{tabular}

Sumber: Data diolah (2018)

Berdasarkan rasio likuiditas Bank Panin Syariah menempati peringkat pertama, pada indikator profitabilitas Bank Syariah Mandiri yang berada pada peringkat pertama, pada indikator produktifitas Bank Syariah Mega Indonesia menempati peringkat pertama, dan pada indikator insolvensi Bank Panin Syariah yang menempati peringkat pertama.

Sebaliknya pada rasio indikator likuiditas Bank Syariah Mega menempati posisi terakhir dalam sampel yaitu peringkat 10. Demikian pula Bank Syariah Bukopin berada di peringkat terkahir pada rasio profitabilitas. Pada produktifitas Bank Victoria Syariah yang menempati peringkat terakhir dan Bank Muamalat Indonesia berada pada peringkat terakhir indikator insolvensi.

Tabel 3. Analisis Komparatif dari Kinerja Keuangan

\begin{tabular}{lcrrrr}
\hline & X1 & X2 & \multicolumn{1}{c}{ X3 } & \multicolumn{1}{c}{ X4 } & \multicolumn{1}{c}{ Z } \\
\hline Mann-Whitney U & 6.000 & 3.000 & 4.000 & 2.000 & 6.000 \\
Wilcoxon W & 27.000 & 13.000 & 14.000 & 23.000 & 27.000 \\
Z & -1.279 & -1.919 & -1.706 & -2.132 & -1.279
\end{tabular}

Ihtifaz: Journal of Islamic Economics, Finance, and Banking 


\begin{tabular}{|c|c|c|c|c|c|c|}
\hline & $\begin{array}{l}\text { Asymp. Sig. } \\
\text { (2-tailed) }\end{array}$ & .201 & .055 & .088 & .033 & .201 \\
\hline IHTIFAZ - JIEFB & $\begin{array}{l}\text { Exact Sig. } \\
{[2 *(1 \text {-tailed }} \\
\text { Sig.)] }\end{array}$ & $.257^{\mathrm{b}}$ & $.067^{b}$ & $.114^{b}$ & $.038^{\mathrm{b}}$ & $.257^{b}$ \\
\hline
\end{tabular}
a. Grouping Variable: Jenis_Bank
b. Not corrected for ties.

Untuk menguji perbedaan Z-Score dan rasio keuangan yang berkaitan dengan kebangkrutan, uji Mann-Whitney sampel kecil dilakukan pada variabel $X_{1}, X_{2}, X_{3}, X 4$, dan Z. Apabila nilai signifikansi yang diperoleh dari hasil SPSS menunjukkan nilai yang sama atau lebih besar dari 0.05 (Sig. < 0.05) maka Ho ditolak. Namun apabila nilai signifikansi yang diperoleh lebih dari 0.05 maka Ho diterima.

Tabel 3 menunjukkan bahwa rasio seperti likuiditas, profitabilitas, dan produktifitas memiliki nilai Sig $>0,05$, yaitu masing-masing 0,201, 0,055 dan 0,088. Dan nilai Z juga memiliki nilai Sig 0,201, maka Ho diterima. Sedangkan nilai sig dari rasio insolvensi $<0,05$, yaitu senilai 0,033, maka Ho ditolak.

Penelitian ini menerangkan bahwa, diantara Bank Umum Syariah Devisa dan Bank Umum Syariah non Devisa peran dari rasio likuiditas, profitabilitas dan produktifitas dalam menunjukkan kebangkrutan adalah sama. Namun, peran dari rasio insolvensi dalam resiko kebangkrutan pada Bank Umum Syariah Devisa dan Bank Umum Syariah non Devisa adalah berbeda. Dalam hasil analisis uji beda di atas hipotesis $\mathrm{H}_{1}, \mathrm{H}_{2} \mathrm{a}$, $\mathrm{H}_{2} \mathrm{~b}$, dan $\mathrm{H}_{2} \mathrm{C}$ ditolak, sedangkan $\mathrm{H}_{2}$ d diterima.

\section{ANALISIS}

Hasil penelitian menunjukkan bahwa berdasarkan rasio likuiditas, profitabilitas, dan produktifitas yang berhubungan dengan kebangkrutan tidak terdapat perbedaan pada Bank Umum Syariah Devisa dan Bank Umum Syariah non Devisa. Tetapi pada rasio insolvensi yang berkaitan dengan kebangkrutan pada Bank Umum Syariah Devisa dan Bank Umum Syariah non Devisa terdapat perbedaan karena nilai sig $<0,05$. Oleh karena itu, ini membuktikan bahwa tidak adanya perbedaan prediksi kebangkrutan pada Bank Umum Syariah devisa dan Bank Umum Syariah non Devisa disebabkan oleh tidak adanya perbedaan rasio keuangan yang berkaitan dengan kebangkrutan kecuali insolvensi.

Meskipun telah diketahui bahwa Bank Devisa memiliki risiko yang lebih dalam hal risiko nilai tukar namun ternyata hal tersebut tidak menyebabkan adanya perbedaan dalam hal rasio keuangan dan prediksi kebangkrutan menurut metode Altman kecuali pada rasio insolvensi.

Hasil pengujian hipotesis diketahui bahwa antara Bank Umum Syariah Devisa dan Bank Umum Syariah non Devisa tidak ada perbedaan 
yang signifikan dalam hal Likuiditas menurut model Altman. Hal ini dikarenakan Bank Syariah Devisa dan Bank Syariah non Devisa tetap dapat menjaga likuiditas dengan baik. Jadi dalam likuiditas status bank tersebut tidak mempengaruhi, ditambah lagi peraturan BI tentang likuiditas bank yang juga tidak membedakan apakah itu Bank Devisa ataupun non Devisa.

Rasio Profitabilitas antara Bank Umum Syariah Devisa dan Bank Umum Syariah non Devisa juga tidak terdapat perbedaan yang signifikan. Walaupun Bank Devisa memiliki tambahan peghasilan dalam hal transaksi valuta asing, hal ini tidak menyebabkan adanya perbedaan dalam hal profitabilitas antara kedua jenis bank tersebut. Dalam hal ini Bank Syariah Devisa dan Bank Syariah non Devisa memiliki kemampuan yang tidak berbeda secara signifikan dalam menghasilkan laba yang tidak dibagikan kepada para pemegang saham. Dengan kata lain, laba ditahan menunjukkan berapa banyak pendapatan perusahaan yang tidak dibayarkan dalam bentuk deviden kepada para pemegang saham.

Rasio Produktivitas menurut model Altman juga ditemukan tidak ada perbedaan yang signifikan antara Bank Umum Syariah Devisa dan Bank Umum Syariah non Devisa. Rasio ini merupakan variabel yang mengukur kemampuan operasional bank dalam mendapatkan laba dari penggunaan aktiva yang dimiliki. Hasil tersebut dapat diartikan bahwa Bank Umum Syariah Devisa dan Bank Umum Syariah non Devisa tidak memiliki perbedaan yang signifikan dalam hal kemampuan operasionalnya.

Indikator keuangan yang terakhir dalam model Altman adalah Insolvensi, pada indikator ini juga ditemukan ada perbedaan yang signifikan antara Bank Umum Syariah Devisa dan Bank Umum Syariah non Devisa. Antara Bank Syariah Umum Devisa dan Bank Umum Syariah non Devisa memiliki kemampuan yang berbeda dalam hal kemampuan untuk menjamin setiap hutangnya dengan modal sendiri yang dimiliki. Hal tersebut dapat dilihat pula pada pembahasan tabel 1 sebelumnya. Bahwa rata-rata rasio kelompok Bank Umum Syariah non Devisa di atas rata-rata kelompok Bank Umum Syariah Devisa.

Prediksi kebangkrutan menurut model Altman ditemukan tidak memiliki perbedaan. Hal dikarenakan tidak adanya perbedaan pada rasio likuiditas, profitabilitas, produksifitas yang berhubungan dengan kebangkrutan pada model altman antara Bank Umum Syariah Devisa dan Bank Umum Syariah non Devisa kecuali insolvensi. Maka dapat dinyatakan bahwa penyebab prediksi kebangkrutan yang tidak berbeda secara signifikan pada Bank Umum Syariah Devisa dan Bank Umum Syariah non Devisa adalah karena rasio keuangan yang tidak berbeda secara signifikan kecuali insolvensi. 


\section{KESIMPULAN}

Berdasarkan hasil uji beda menunjukkan bahwa prediksi Bank Umum IHTIFAZ - JIEFB Syariah Devisa maupun Bank Umum Syariah non Devisa bisa dikatakan tidak memiliki perbedaan, dilihat dari hasil uji beda Asymp Sig 0,201 $>0,05$. Dapat dilihat pula pada peringkat antara Bank Umum Syariah Devisa dan Bank Umum Syariah non Devisa. Peringkat yang dimiliki Bank Umum Syariah Devisa berada pada peringkat tertinggi, menengah dan terakhir, begitu pula pada Bank Umum Syariah non Devisa yang memiliki peringkat yang merata.

Untuk mencapai tujuan kedua dapat dilihat pada perbandingan rasio keuangan seperti likuiditas, profitabilitas dan produktifitas yang berkaitan dengan kebangkrutan pada Bank Umum Syariah Devisa dan Bank Umum Syariah non Devisa tidak ada perbedaan. Namun pada rasio insolvensi ditemukan memilik perbedaan. Oleh karena itu, terbukti penyebab tidak adanya perbedaan pada prediksi kebangkrutan Bank Umum Syariah Devisa dan Bank Umum Syariah non Devisa adalah karena rasio keuangan yang berkaitan dengan kebangkrutan tidak ada perbedaan kecuali rasio insolvensi.

Dalam penelitian ini diketahui bahwa perbedaan status Bank tidak akan menyebabkan adanya perbedaan pada prediksi kebangkrutan sebuah Bank, meskipun secara rata-rata risiko Bank Devisa sedikit lebih tinggi dari Bank non Devisa, apabila dilihat nilai masing-masing Bank, ada Bank non Devisa yang memiliki resiko lebih tinggi dari Bank Devisa. Penelitian ini akan memberikan kontribusi mengenai prediksi kebangkrutan pada setiap Bank yang menjadi sampel serta peran penting dari indikator kinerja keuangan yang tidak menyebabkan perbedaan pada status bank yang berbeda dalam konteks ini adalah Bank Syariah Devisa dan non Devisa.

\section{REFERENSI}

Adnan, Muhammad Akhyar dan Eha Kurniasih. (2000). Analisa Tingkat Kesehatan Perusahaan Untuk Memprediksi Potensi Kebangkrutan Dengan Pendekatan Altman. Jurnal Akuntansi dan Auditing Indonesia. Vol. 4. No. 2.

Almilia, Spica Luciana. (2004). Analisis Faktor-faktor yangMempengaruhi Kondisi Financial Distress suatu Perusahaan yang terdaftar di Bursa Efek Jakarta. Jurnal Akuntansi Indonesia (JRAI). Vol 7. No. 1.

Altman, E. I. (1968). Financial Ratios, Discriminant Analysis and Prediction of Corporate Bankruptcy. The Journal of Finance. Vol. 13. No. 4.

Altman, E. I. (2000). Predicting financial distress of companies: Revisiting the Z- Score and Zeta ${ }^{\circledR}$ Models. Updated from E. Altman, Financial Ratios, Discriminant Analysis and the Prediction of Corporate Bankruptcy. Journal of Banking \& Finance, 1. 
Endri. (2009). Prediksi Kebangkrutan Bank Untuk Menghadapi dan Mengelola Perubahan Lingkungan Bisnis: Analisis Model Altman's Z-Score. Perbanas Quarterly Review. Vol. 2 No. 1.

Hadi, Syamsul dan Atika Anggraeni. (2008). Pemilihan Prediktor Delisting Terbaik (Perbandingan antara The Zmijewski Model, The Altman Model, dan The Springate Model), Jurnal Akuntansi dan Auditing Indonesia, Vol. 12:2, Desember 2008.

Jan, Amin dan Maran Marimuthu. 2015. Altman Model and Bankruptcy Profile of Islamic Banking Industry: A Comparative Analysis on Financial Performance. International Journal of Business and Management. Vol. 10. No. 7.

Kasiram, Moh. (2008). Metode Penelitian Kualitatif-Kuantitatif. Jakarta: UIN Malang Press.

Kasmir. (2014). Analisis Laporan Keuangan. Jakarta: PT. Raja Grafindo Persada.

Kahya, E. dan P. Theodossiou. (1999). Predicting Corporate Financial Distress: A Time-Series CUSUM Methodology. Review of Quantitative Finance and Accounting, 13. 4; ABI/INFORM Global.

Muhammad. (2005). Bank Syariah Problem dan Prospek Perkembangan di Indonesia. Yogyakarta: Graha Ilmu.

Nurdin, Irsyad. (2012). Peranan Analisis Metode Z-Score dalam Memprediksi Kebangkrutan Suatu Perusahaan dan Kaitannya Terhadap Harga Saham (Studi Pada Perusahaan Perbankan Yang Go Public Di Bursa Efek Indonesia). Jurnal Skripsi Fakultas Ekonomi Jurusan Akuntansi. Universitas Siliwangi. Terpublikasikan Melalui Link: journal.unsil.ac.id/download.php/. Diunduh pada tanggal 25 April 2016.

Sanjaya, Andi, Lindrianasari, Aminah. (2015). Bankruptcy Analisis of Banking Companies in Indonesia Period 2001-2012 (Using the Altman Z-Score Model). Internasional Journal on Economics and Social Sciences Vol. 1, No. 1.

Suliyanto. (2014). Statistik Non Parametrik dalam Aplikasi Penelitian. Yogyakarta: C.V Andi Offset.

https://finance.detik.com/moneter/1115753/kronologi-dan-latarbelakang-krisis-finansial-global 19/04/2017. Diakses pada 11 Februari 2017 pukul 10:54.

http: / / www.suaramerdeka.com/v1/index.php/read/ cetak/2009/04/21/60391/Aset-Bank-IFI-Sudah-Diamankan. Diakses pada 10 Februari 2017 pukul 11:06.

http://www.suaramerdeka.com/v1/index.php/read/cetak/2013 /12/09/245653/Penyelesaian-Kasus-Century-Tergantung-SBYBoediono. Diakses pada 10 Februari 2107 pukul 10:59.

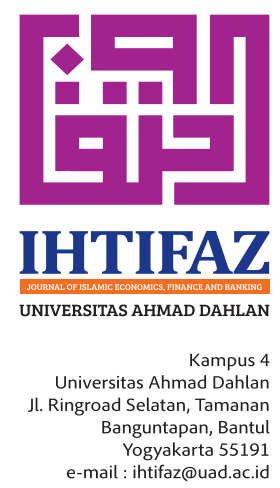

